\title{
Comparison of elemental concentration in near-surface late Holocene sediments and precipitation regimes of the Yucatán Peninsula (Mexico): a preliminary study
}

\author{
P. D. Roy ${ }^{(1)}$, N. Torrescano-Valle(2), D. del Socorro Escarraga-Paredes ${ }^{(2)}$, A. A. Vela-Pelaez ${ }^{(2)}$ \\ and R. Lozano-Santacruz ${ }^{(1)}$
}

(1) Instituto de Geología, Universidad Nacional Autónoma de México, Ciudad Universitaria, CP 04510, Ciudad de México, México roy@geologia.unam.mx; rufino@unam.mx

(2) El Colegio de la Frontera Sur (ECOSUR), Unidad Chetumal, Av. Centenario, Km. 5.5, A.P. 424, 77014, Chetumal, Quintana Roo, México. ntorresca@ecosur.mx; descarra@ecosur.edu.mx; avela@ecosur.edu.mx

\begin{abstract}
Paleoclimate research in theYucatán Peninsula of Mexico has mainly involved fossil pollen preserved in sedimentary archives whilst geochemistry has received limited attention. In this study, we compared concentrations of $\mathrm{K}, \mathrm{Ti}, \mathrm{Fe}, \mathrm{Ca}$ and $\mathrm{Sr}$ in 35 near-surface late Holocene sediments collected from different permanent and seasonal water bodies across the peninsula with mean annual precipitation of $600-1600 \mathrm{~mm}$ in order to explore the relationship between concentrations of inorganic elements and precipitation. The calcareous provenance has a diluting effect and sediments have less $\mathrm{K}, \mathrm{Ti}$ and $\mathrm{Fe}$ (associated with clastics) and more $\mathrm{Ca}$ and $\mathrm{Sr}$ (associated with carbonate and evaporite) compared to the Upper Continental Crust. Individual elements and ratios of $\mathrm{K} / \mathrm{Ca}, \mathrm{Ti} / \mathrm{Ca}$ and $\mathrm{Fe} / \mathrm{Ca}$ in samples with minimal clastics did not show any relationship with precipitation. Average values of elemental ratios in sediments with more clastics increase as the mean annual precipitation increases. However, the sampling protocol and presence of most of the sampled water bodies being in a single precipitation cluster (i.e. $1200-1400 \mathrm{~mm} / \mathrm{year}$ ) did not allow a complete evaluation of the potential correlation between precipitation and elemental ratios. Considering that the concentration of Ti is low in sediments of the limestone-rich Yucatán Peninsula and Fe is mobile in anoxic depositional environments, the $\mathrm{K} / \mathrm{Ca}$ ratio can be used as a preliminary proxy to evaluate precipitation in sedimentary records.
\end{abstract}

Keywords: geochemistry, element ratio, paleo-precipitation proxy, calcareous provenance,Yucatán Peninsula.

\section{Comparación de concentración elemental en sedimentos superficiales del Holoceno tardío y los regímenes de precipitación en la Península de Yucatán, México: un estudio preliminar}

\begin{abstract}
RESUMEN
La investigación paleoclimática en la Península de Yucatán (YP) de México involucra principalmente el polen fósil preservado en archivos sedimentarios, mientras que la geoquímica ha recibido menos atención. En este estudio, se compararon las concentraciones de $\mathrm{K}, \mathrm{Ti}$, Fe, Ca y Sr, en 35 muestras superficiales de sedimento del Holoceno tardío, colectadas en un gradiente de precipitación entre 600-1600 mm/a, a lo largo de la YP, con el objetivo de establecer un testigo de la paleo-precipitación para la región. El origen calcáreo tiene un efecto de dilución en las concentraciones elementales, provocando que los sedimentos presenten baja cantidad de K, Ti y Fe (elementos asociados con clásticos) y mayor cantidad de Ca y Sr (elementos asociados con carbonato y evaporitas), en comparación con la corteza continental superior. Los elementos individuales y las relaciones de $\mathrm{K} / \mathrm{Ca}$, Ti/Ca y Fe/Ca en muestras con cantidades mínimas de clástico, no muestran una relación con la precipitación. Los valores promedio de la relación elemental en sedimentos con más clásticos, muestra tendencias positivas con la precipitación. No obstante, el protocolo de muestreo y la presencia de un
\end{abstract}


P. D. Roy, et al., 2018. Comparison of elemental concentration in near-surface late Holocene... Boletín Geológico y Minero, 129 (4): $693-706$

mayor número de cuerpos de agua investigados en un simple aglomerado (p. ej. 1200-1400 mm/a) no permitió completar la evaluación de la correlación potencial entre precipitación y la relación elemental. Considerando que la concentración de Ti en los sedimentos ricos en calizas de la PY es bajo y el Fe es móvil en ambientes de depositación anóxicos, la relación $\mathrm{K} / \mathrm{Ca}$ puede ser utilizada como un testigo preliminar para reconstruir la variación de la paleo-precipitación.

Palabras clave: Geoquímica, Relación elemental, Testigo de paleo-precipitación, Procedencia calcárea, Península de Yucatán.

\section{VERSIÓN ABREVIADA EN CASTELLANO}

\section{Introducción}

El calentamiento global antropogénico actual ha incrementado la curiosidad científica para comprender las respuestas de los diferentes ecosistemas, del régimen de precipitación y de la desertificación, ante el cambio climático experimentado en el pasado geológico (Masson-Delmotte et al., 2013). Los cambios estratigráficos en la fraccionación de isótopos estables, el contenido macro y micro fósil y la abundancia de los minerales en los archivos sedimentarios, han sido utilizados para reconstruir el ambiente del pasado y las condiciones paleo-climáticas (Curtis et al., 1996; Hodell et al., 2005; Carillo-Bastos et al., 2010; Torrescano-Valle e Islebe, 2015; Roy et al., 2016). La mayoría de los estudios paleoambientales realizados en la Península de Yucatán están basados en registros fosilizados de polen, pero poco se conoce sobre las concentraciones de elementos inorgánicos de los registros sedimentarios (Islebe y Sánchez, 2002; Carillo-Bastos et al., 2010; AragónMoreno et al., 2012; Gutierrez-Ayala et al., 2012; Torrescano-Valle e Islebe, 2006, 2012). En este artículo se presentan una comparación de las concentraciones de K, Ti, Fe, Ca y Sr, registradas en 35 muestras de sedimento superficial del Holoceno tardío, colectadas en diferentes regímenes de precipitación a lo largo de la Península. La comparación y evaluación del efecto de la geología en la composición química de los sedimentos, permite, establecer un testigo de paleo-precipitación. La hipótesis de trabajo se basa en el hecho de que los minerales clásticos terrígenos son transportados desde el origen hacia la cuenca sedimentaria por escorrentía. Las concentraciones de K, Ti y Fe reflejan la abundancia de los minerales clásticos terrígenos, dicha concentración puede incrementar en sedimentos depositados durante los regímenes de alta precipitación.

\section{Zona de estudio y muestreo}

La Península de Yucatán (PY) se localiza en el sureste de México, es un lecho de roca caliza del Neógeno, con cantidades menores de lutitas del mismo periodo, también se encuentran areniscas y aluvión del Cuaternario (Servicio Geológico Mexicano, 2005a, 2005b; Fig. 1A). La PY recibe precipitación durante el verano y el otoño con una distribución bimodal y experimenta un periodo seco a mitad del verano llamado canícula (Magaña et al., 1999). Las masas de aire polar continental promueven lluvias durante el invierno y primavera aunque en menor cantidad (Mendoza et al., 2006). Se colectaron 35 muestras superficiales de sedimento provenientes de diferentes sitios de la Península de Yucatán de México (en los estados de Campeche, Yucatán y Quintana Roo; Fig. 1B). Estos sitios reciben una precipitación media anual entre 600 y $1600 \mathrm{~mm}$. Las muestras fueron agrupadas en 5 grupos: 600-800 mm (número de muestras=2), 800-1000 mm (n=5), 1000-1200 $\mathrm{mm} / \mathrm{a}(\mathrm{n}=5), 1200-1400 \mathrm{~mm}(\mathrm{n}=18)$ y $1400-1600 \mathrm{~mm}(\mathrm{n}=5)$.

\section{Materiales y métodos}

Las muestras fueron secadas a $40^{\circ} \mathrm{C}$ y homogenizadas por medio de un mortero de ágata hasta la obtención de un polvo fino. Las concentraciones de $\mathrm{K}, \mathrm{Ti}$, Fe, Ca y Sr fueron medidas en un analizador marca Thermo Scientific Niton XL3t para medir la florescencia de rayos X (FRX). Además todos los elementos fueron medidos en un analizador convencional de FRX marca Siemens, en discos fusionados y prensados elaborados con material en forma de pellets de las 35 muestras secas y homogéneas. Los resultados del análisis FRX convencional muestran alta y positiva correlación $(r>0.9, p<0.05)$ con los resultados obtenidos en Niton FRX (Fig. 2). Por medio de las líneas de regresión es posible corregir los datos de concentraciones obtenidos en el Niton XL3t, comparándolos con los resultados obtenidos de convencional FRX. Análisis estadísticos de correlación y conglomerados fueron realizados para identificar los comportamientos de los elementos. 
P. D. Roy, et al., 2018. Comparison of elemental concentration in near-surface late Holocene... Boletín Geológico y Minero, 129 (4): $693-706$

\section{Resultados y discusión}

\section{Concentración elemental vs. Geología}

Los sedimentos superficiales analizados para la PY presentan las siguientes concentraciones: $0.91 \%$ (media=0.31\%) de K, 0.01-0.76\% (media=0.34\%) de Ti, 0.01-3.12\% (media=1.22\%) de Fe, 0.40-37.70\% (media=14.0\%) de Ca y $27-4059$ ppm (media=724 ppm) de Sr (Tabla 1). Ti y Fe muestran una distribución similar ( $r=0.9, p<0.05)$, la distribución de $K$ es parcialmente comparable con las distribuciones de Ti y Fe ( $r=0.5$, $p<0.05)$. La distribución de Ca y Sr son comparables $(r=0.7, p<0.05)$, ambos se relacionan negativamente con $K$, Ti y Fe (r=0.6-0.8, p<0.05). El primer grupo de elementos ( $K, \mathrm{Ti}$ y Fe) está asociado con silicatos clásticos y aluminosilicatos, el segundo grupo de elementos (Ca y Sr) está presente en los carbonatos y evaporitas (Fig. 3).

Se observaron diferencias entre la composición química de los sedimentos colectados en sitios con geología similar. Las muestras colectadas en sitios con dominante contenido de calizas muestran diferentes abundancias de elementos asociados con minerales clásticos y carbonatos (Tabla 1). Las concentraciones de $K, \mathrm{Ti}$ y Fe son relativamente altas en los sedimentos superficiales de la PY, comparadas con la composición química de caliza promedio (Tabla 1; Mason y Moore, 1982), lo cual sugiere la influencia de rocas sedimentarias ricas en silicatos. A través de la erosión de las margas intercaladas en las calizas, areniscas y lutitas, los sedimentos superficiales recibieron cantidades variables de K, Ti y Fe.

\section{Concentración elemental vs. Precipitación}

La erosión y escorrentía ocurren en un ambiente de oxidación con $\mathrm{pH}$ y temperatura uniforme (Taylor y McLennan, 1985). Bajo estas condiciones, el potencial iónico controla la transportación de diferentes elementos, ya sea como material particulado o en el estado soluble (Mason y Moore, 1982). Las concentraciones de K, Ti y Fe reflejan abundancia de clástos terrígenos transportados por la escorrentía. Alta precipitación y escorrentía pueden depositar sedimentos con mayor concentración de K, Ti y Fe, y regímenes con baja precipitación pueden depositar menor cantidad de K, Ti y Fe. De forma similar, sedimentos depositados en regímenes de baja precipitación podrían tener mayor cantidad de Ca y Sr junto con la precipitación de carbonatos y evaporitas. En este trabajo se comparan concentraciones elementales de muestras superficiales de sedimento con la precipitación media anual (Fig. 4). Sin embargo, las concentraciones elementales son variables en cada régimen de precipitación y no presentan una clara tendencia con respecto a la precipitación media anual. Los sitios con precipitación media anual similar muestran diferentes concentraciones elementales. La presencia de marga y areniscas en conjunto con calizas posiblemente aportaron mayor concentración de K, Fe y Ti, en comparación con sitos constituidos predominantemente por calizas.

\section{Relación elemental vs. Precipitación}

Se utilizaron la relación entre elementos asociados con los minerales clásticos y elementos presentes en carbonatos y evaporitas (p.ej. K/Sr, Ti/Sr, Fe/Sr, K/Ca, Ti/Ca y Fe/Ca), para reducir el efecto de dilución por los carbonatos y evaporitas en la abundancia de minerales clásticos (p. ej. Weltje y Tjallingii, 2008). En la figura 5 se muestran los índices de variación elemental en sedimentos con respecto a la precipitación media anual de los sitios de muestreo. En general, los sedimentos con bajos valores de proporción elemental están presentes en sitios con menor precipitación media anual y no muestran una clara tendencia cuando la precipitación media anual incrementa. Estos valores pueden estar asociados a una baja escorrentía que aporta una mínima cantidad de clásticos y una menor erosión de los depósitos dominados por calizas (Tabla 1). Los sedimentos con menos clásticos ( $p$. ej. K, Ti y Fe) no responden a la variable precipitación (Fig. 5). Sin embargo, se identificaron efectos intrínsecos del diseño de muestreo, por ejemplo, existe un mayor número de muestras (n=18) con precipitación entre 1200 y 1400 mm/a y un menor número de muestras ( $n=2)$ con precipitación entre 600 y 800 mm/a. Además se registró variación entre las cantidades de marga rica en clásticos y areniscas alrededor de los sitios de muestreo con regímenes de 1200-1400 mm/a y 1400-1600 mm/a que pueden contribuir a las variaciones en las abundancias de K, Fe y Ti. Para disminuir los efectos del muestreo y de la variable geológica del depósito, los valores promedio de K/Ca, Ti/Ca, Fe/Ca, K/Sr, Ti/Sr y Ti/Sr fueron comparados con la precipitación promedio anual. Las proporciones de K/Ca, Ti/Ca y Fe/Ca muestran tendencias positivas con la precipitación (Fig. 6). La proporción K/Ca es mejor que el Ti/Ca y Fe/Ca para inferir la variación de la paleo-precipitación en la Península, debido que Ti presenta baja abundancia y Fe puede ser móvil en ambientes anóxicos. Los resultados sugieren que los sedimentos con más clásticos responden mejor a la variación de precipitación y que la proporción K/Ca puede ser utilizada como un testigo preliminar para infe- 
P. D. Roy, et al., 2018. Comparison of elemental concentration in near-surface late Holocene... Boletín Geológico y Minero, 129 (4): $693-706$

rir la paleo-precipitación en la Península. No obstante, se requiere incrementar el análisis de muestras de sedimento superficial provenientes de sitios con diferente régimen de precipitación a lo largo de la Península de Yucatán.

\section{Conclusiones}

Sedimentos que provienen de sitios con geología similar tienen composición química diferente. Además de la caliza dominante, la erosión de las lutita, marga y arenisca aportan diferentes cantidades de K, Ti y Fe.

La falta de relación entre las concentraciones elementales y la precipitación media anual es producto del efecto de dilución de carbonatos y evaporitas en los minerales clásticos.

Los valores promedio de $\mathrm{K} / \mathrm{Ca}$, Ti/Ca y $\mathrm{Fe} / \mathrm{Ca}$ en sedimentos con alta abundancia de clásticos incrementan con respecto a un aumento en el valor de la precipitación media anual. La relación K/Ca es mejor que la de Ti/Ca y Fe/Ca, para inferir la variación de la paleo-precipitación en la Península de Yucatán. Sin embargo, se requiere incrementar muestras de sedimento provenientes de los sitios con bajo régimen de precipitación para poder evaluar la relación entre relación elemental y precipitación.

\section{Introduction}

Anthropogenic global warming of the modern era has increased scientific curiosity to document the responses of different ecosystems and regimes of precipitation and desertification to climate change over the geological past (Masson-Delmotte et al., 2013). Stratigraphic changes of stable isotope fractionation, macro and micro fossil content and abundance of minerals in sedimentary archives have been used to infer past environmental and climatic conditions (Curtis et al., 1996; Hodell et al., 2005; Carillo-Bastos et al., 2010; Torrescano-Valle and Islebe, 2015; Roy et al., 2016). Elemental concentration indirectly estimates abundances of both the allochthonous and autochthonous minerals present in sediment and is less time consuming compared to the analysis of the micro-fossils and relatively less expensive compared to the analysis of stable isotopes. The chemistry of allochthonous fraction in sedimentary archives is affected by chemical weathering of clastic minerals during erosion and transportation from the source region and also by post-depositional alterations such as diagenesis and metasomatism (Nesbitt and Young, 1982; Mason and Moore, 1982; Taylor and McLennan, 1985; Cohen, 2003). However, it is possible to quantify these effects and select elements that best preserve a record of source rock erosion and transportation of terrigenous minerals by fluvial/pluvial activities in humid intervals and aeolian activity during arid intervals (Roy et al., 2013; Roy et al., 2015).

The pioneering studies of Haug et al. $(2001,2003)$ and Peterson and Haug (2006) presented $\mathrm{Ti}$ and $\mathrm{Fe}$ concentrations in sediments of the Cariaco Basin off Venezuela as a proxy to estimate riverine discharge and varying rainfall associated with the dynamics of the Inter-Tropical Convergence Zone. Over the last decade, several researchers have successfully used concentrations of different elements in lacustrine sediments from distinct geological terrains to reconstruct the Late Quaternary paleoclimate of different parts of Mexico and infer the associated climatic forcings such as the North American Monsoon, El Niño Southern Oscillation, etc. (Metcalfe et al., 2010; SosaNajera et al., 2010; Lozano-García et al., 2015; Roy et al., 2010, 2015, 2016). Compared to the rest of Mexico, chemical composition of sedimentary archives from the Yucatán Peninsula has received significantly less attention (Curtis et al., 1996; Hodell et al., 2005; Carillo-Bastos et al., 2010). Most of the studies related to the paleoecology and paleoclimate of the peninsula are based on fossil pollen preserved in sediments of lacustrine basins as well as coastal swamps and marshes (Islebe and Sánchez, 2002; Carillo-Bastos et al., 2010; Aragón-Moreno et al., 2012; Gutíerrez-Ayala et al., 2012; Torrescano-Valle and Islebe, 2006, 2012) and there is hardly any proxy register that involves inorganic element concentrations in sedimentary archives. In this paper, we present concentrations of $\mathrm{K}, \mathrm{Ti}, \mathrm{Fe}, \mathrm{Ca}$ and $\mathrm{Sr}$ in 35 near-surface late Holocene sediment samples collected from different precipitation regimes across the Yucatán Peninsula. Elemental concentrations of sediments are compared with mean annual rainfall of the sampling sites in order to establish a proxy for precipitation after evaluating the effect of geology. Our working hypothesis is based on the fact that terrigenous clastic minerals are transported from the catchment area into the sedimentary basins by runoff. Concentrations of $\mathrm{K}, \mathrm{Ti}$ and $\mathrm{Fe}$ would reflect abundance of the terrigenous clastic minerals and their concentrations would increase in sediments deposited during regimes of higher precipitation. 


\section{Study area and sampling}

The Yucatán Peninsula is located in southeastern Mexico and its bedrock has dominant Neogene limestone and minor amounts of Neogene shale and Quaternary sandstone and alluvium (Servicio Geologico Mexicano, 2005a, 2005b; Fig. 1A). It receives precipitation during the summer and autumn months in a bimodal distribution with a mid-summer dry spell (Magaña et al., 1999). The polar continental air masses bring minor winter and spring precipitations (Mendoza et al., 2006). A total of 35 surface sediments were collected from different sites across the peninsula (i.e. the states of Campeche, Yucatán and Quintana Roo, Fig. 1A) from permanent (e.g. lakes, swamps) as well as seasonal water bodies. The sampling sites receive mean annual precipitation of between 600 and 1,600 mm (INEGI, 2006; Fig. 1B). We divided the sampling sites into groups with different amounts of mean annual precipitation: $600-800 \mathrm{~mm}$ $(n=2), 800-1,000 \mathrm{~mm}(\mathrm{n}=5), 1,000-1,200 \mathrm{~mm}(\mathrm{n}=5)$, $1,200-1,400 \mathrm{~mm}(\mathrm{n}=18)$ and $1,400-1,600 \mathrm{~mm}(\mathrm{n}=5)$. More than half of the sampling sites are within the precipitation group of $1,200-1,400 \mathrm{~mm}$ due to the relatively easier access to these sampling sites as well as the location of most of the water bodies being in higher precipitation regimes.

\section{Material and methods}

Surface sediments comprise organic-rich clay as well as calcareous clay and some of them contain abundant root remnants and coarser sand and gravel (Table 1). Samples were oven dried at $40^{\circ} \mathrm{C}$ and sieved to remove the root remnants and coarser fragments and subsequently homogenized and ground with an agate mortar and pestle. Concentrations of $\mathrm{K}, \mathrm{Ti}, \mathrm{Fe}$, $\mathrm{Ca}$ and $\mathrm{Sr}$ were measured in dry and powdered samples using the portable Thermo Scientific Niton XL3t $X$-ray fluorescence (XRF) and non-destructive sample preparation technique. Analysis of three different geological reference materials $(\mathrm{OU}-8, \mathrm{BCU}-3$ and IGLA-1) suggests an error of $1-6 \%$ in precision and an error of $1.5-392 \%$ in accuracy. Concentrations of $\mathrm{K}$ in 7 samples, $\mathrm{Ti}$ in 11 different samples and $\mathrm{Fe}$ in one sample remained below the detection limit of the Niton $\mathrm{XRF}$ equipment and hence could not be measured. We measured all the elements again in a conventional Siemens XRF by making a fused disc and a pressed pellet from dry powdered sediments. Approximately $0.8 \mathrm{~g}$ of dry and powder sediment was mixed with 7.2 $\mathrm{g}$ of $(1: 1) \mathrm{LiBO}_{2}$ and $\mathrm{Li}_{2} \mathrm{~B}_{4} \mathrm{O}_{7}$ mixture and this mixture was fused in a Pt/Au (95:5) alloy crisol to analyze the concentrations of $\mathrm{K}, \mathrm{Ti}, \mathrm{Fe}$ and $\mathrm{Ca}$ as per LozanoSantacruz et al. (1995). The concentration of K in one
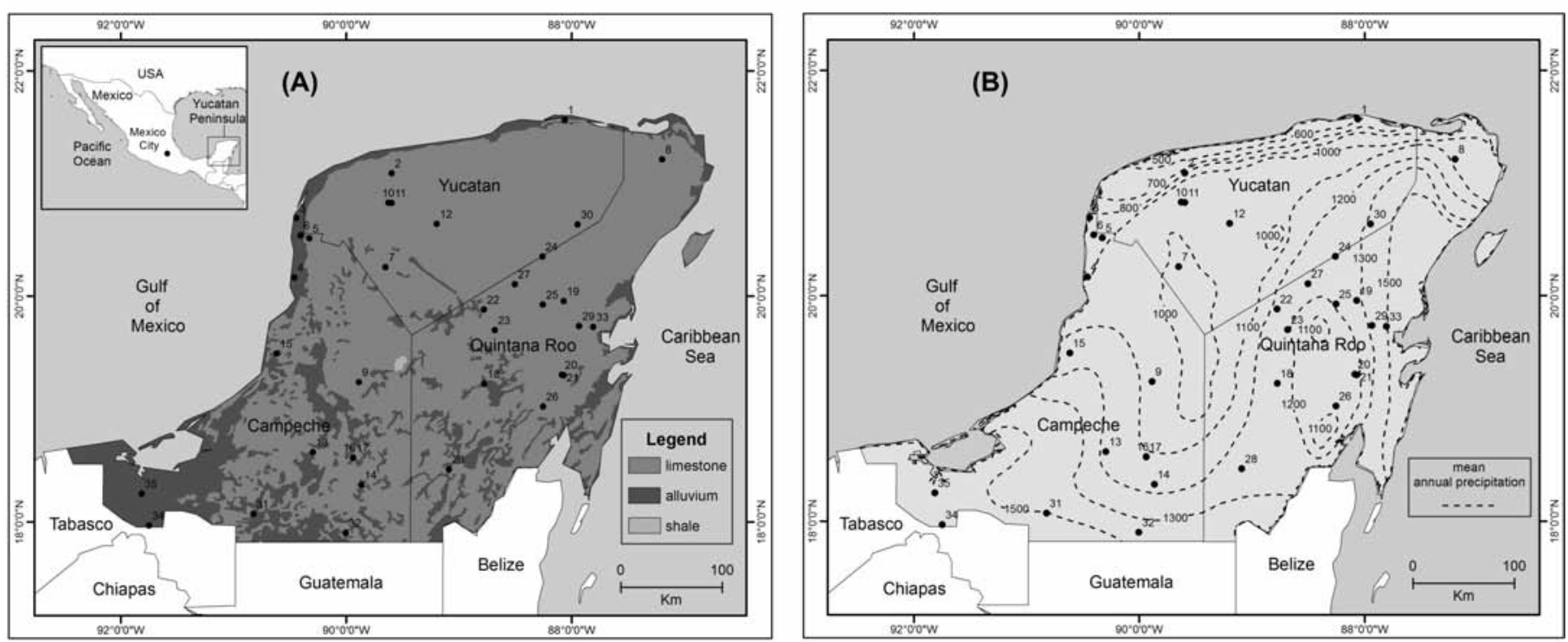

Figure 1. Location of sampling sites in (A) different geological provinces and (B) precipitation regimes of the Yucatán Peninsula of Mexico. Samples were collected from sites with catchments dominantly comprising of limestone. The mean annual precipitation varies between $600 \mathrm{~mm}$ and $1,600 \mathrm{~mm}$.

Figura 1. Localización de los sitios de muestreo en (A) diferentes provincias geológicas y (B) regímenes de precipitación de la Península de Yucatán. Las muestras fueron colectadas en sitios con afloramiento dominante de caliza. La precipitación media anual varía entre 600 y $1600 \mathrm{~mm}$. 
P. D. Roy, et al., 2018. Comparison of elemental concentration in near-surface late Holocene... Boletín Geológico y Minero, 129 (4): $693-706$

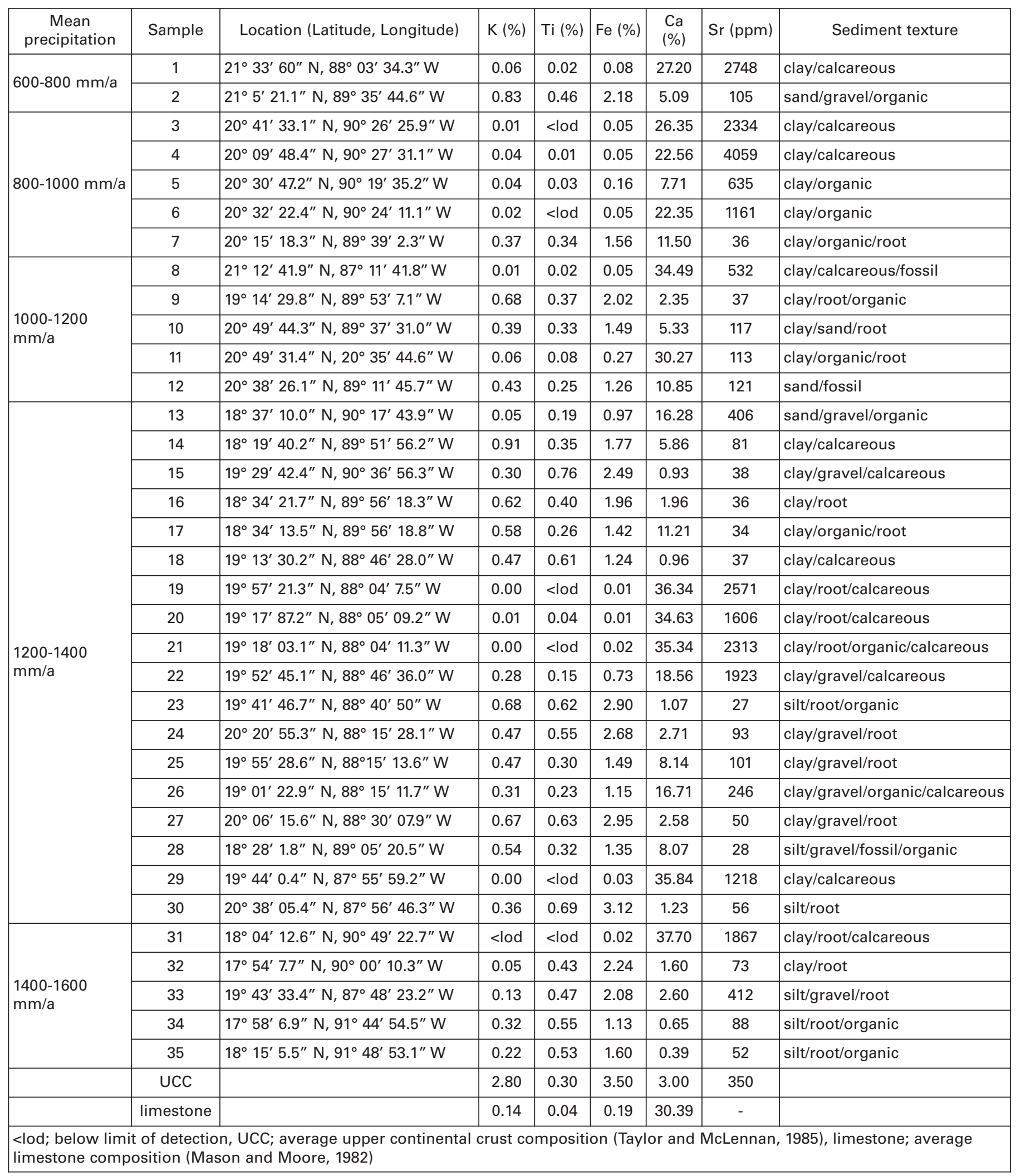

Table 1. Location, chemical composition and texture of samples collected from sites with different mean annual precipitation across the Yucatan Peninsula, Mexico.

Tabla 1. Ubicación, composición química y textura de las muestras colectadas en sitios con diferente precipitación media anual a lo largo de la Península de Yucatán, México. 
sample and $\mathrm{Ti}$ in six samples remained below the detection limit of the equipment. The concentration of $\mathrm{Sr}$ was measured in the pressed pellets prepared from the mixture of $4 \mathrm{~g}$ of powder sediment and binder following the instructions of Lozano-Santacruz et al. (1995) and Verma et al. (1996). Loss on ignition was estimated by a gravimetric method after heating $1 \mathrm{~g}$ of sample up to $950{ }^{\circ} \mathrm{C}$ in a porcelain crucible for 1 hour. The results obtained in the conventional XRF exhibit strong positive correlations $(r>0.9, p<0.05)$ with the results obtained in Niton XL3t XRF (Fig. 2). Concentrations of $\mathrm{K}, \mathrm{Fe}$ and $\mathrm{Ca}$ were overestimated and concentration of $\mathrm{Sr}$ was underestimated in Niton XL3t compared to conventional Siemens XRF. Both types of XRF equipment provided almost similar concentrations of Ti. It was possible to minimize the differences between concentrations obtained with both the XRF spectrometers by using linear regression obtained after comparing results from both. However, we used the results obtained in conventional XRF for interpretation as many samples analyzed in Niton XL3t XRF lacked concentrations of $\mathrm{K}, \mathrm{Ti}$ and $\mathrm{Fe}$ and hence could not be corrected. Statistical analysis (correlation and cluster) was performed using the STATISTICA software to identify the associations of different elements.

\section{Results and discussion}

\section{Elemental concentration vs. geology}

Geology controls the chemical composition of sediments as elements associated with terrigenous clastic
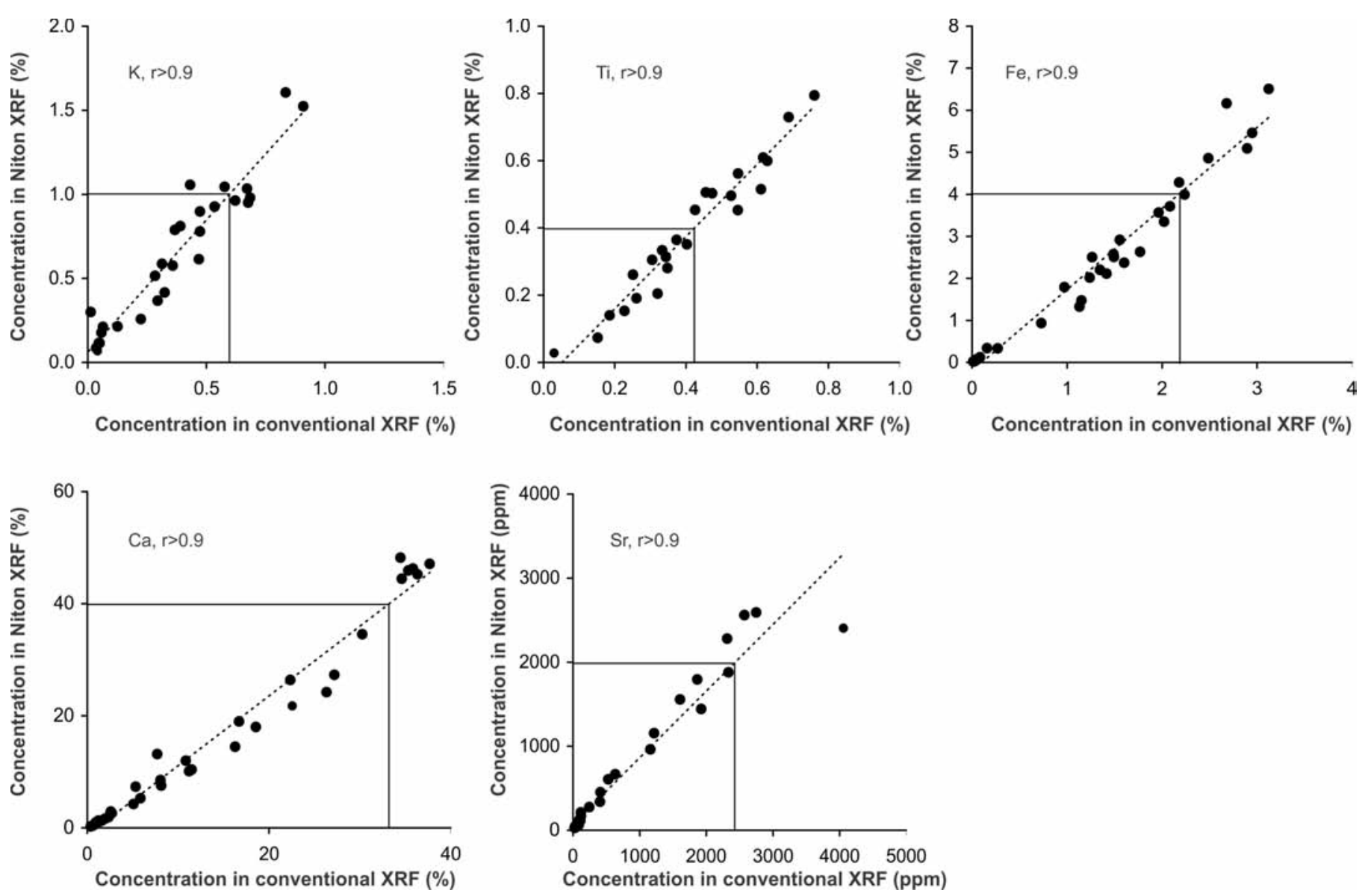

Figure 2. Comparison of concentrations of $\mathrm{K}, \mathrm{Ti}, \mathrm{Fe}, \mathrm{Ca}$ and $\mathrm{Sr}$ obtained in Niton XL3t XRF and traditional Siemens XRF in near-surface sediments of the Yucatán Peninsula. Concentrations of K, Fe and Ca were overestimated and $\mathrm{Sr}$ is underestimated in Niton XRF compared to the traditional XRF.

Figura 2. La comparación de las concentraciones de K, Ti, Fe, Ca y Sr obtenidas por medio de un equipo Niton XL3t XRF y un equipo tradicional Siemens XRF, en sedimentos de la Península de Yucatán. Las concentraciones de K, Fe y Ca fueron sobre-estimadas y el Sr fue sub-estimado en el equipo Niton XL3t XRF en comparación con el equipo tradicional. 
minerals (silicates and aluminosilicates) are derived from erosion of the catchment rocks and elements associated with authigenic minerals (carbonates and evaporites) are deposited from the soluble ions present in water column (Mason and Moore, 1982; Taylor and McLennan, 1985; Cohen, 2003). Surface sediments from the Yucatán Peninsula have up to $0.91 \%$ (mean $=0.31 \%$ ) of $\mathrm{K}, 0.01-0.76 \%$ (mean $=0.34 \%$ ) of $\mathrm{Ti}$, $0.01-3.12 \%$ (mean=1.22\%) of $\mathrm{Fe}, \quad 0.40-37.70 \%$ (mean=14.0\%) of $\mathrm{Ca}$ and $27-4059 \mathrm{ppm}$ (mean=724 ppm) of $\mathrm{Sr}$ (Table 1). Ti and Fe show similar ( $r=0.9$, $\mathrm{p}<0.05)$ distributions and the distribution of $\mathrm{K}$ is comparable partly to the distributions of $\mathrm{Ti}$ and $\mathrm{Fe}(\mathrm{r}=0.5$, $\mathrm{p}<0.05)$. Similarly, the distributions of $\mathrm{Ca}$ and $\mathrm{Sr}$ are comparable $(r=0.7, p<0.05)$ and both of them are negatively related to $\mathrm{K}, \mathrm{Ti}$ and $\mathrm{Fe}(\mathrm{r}=0.6-0.8, \mathrm{p}<0.05)$. The first group of elements $(\mathrm{K}, \mathrm{Ti}$ and $\mathrm{Fe})$ is associated with clastic silicates and aluminosilicates and the second group of elements ( $\mathrm{Ca}$ and $\mathrm{Sr}$ ) is present in carbonate and evaporites (Fig. 3).

Less $\mathrm{K}$ and $\mathrm{Fe}$ in all the samples and higher $\mathrm{Ca}$ and Sr in many of the samples were not similar to the average composition of the Upper Continental Crust (UCC; Taylor and McLennan, 1985) and thus reflect the influence of the regional geology. The geology of the Yucatán Peninsula of Mexico is characterized by abundant limestone and the alluvium produced from erosion of the carbonate-rich lithology (Servicio Geologico Mexicano, 2005a, 2005b). However, we observed dissimilarities between chemical compositions of sediments collected from the sites with similar catchment geology. Samples collected from sites with dominant limestone show different abundances of elements associated with both clastics minerals and carbonates. For example, samples 2, 7, 8 and 26 were collected from sites with dominant limestone and all of them have different concentrations of $\mathrm{K}, \mathrm{Ti}$ and $\mathrm{Ca}$ (Table 1). Sample 2 has higher $\mathrm{K}(0.83 \%)$ and $\mathrm{Ti}(0.46 \%)$ and lower $\mathrm{Ca}(5.09 \%)$ compared to sample 8 (K: 0.01\%; Ti: 0.02\%; Ca: 34.49\%). Even the samples $(3,4,34$ and 35$)$ collected from the alluvium-rich catchment geology have different abundances of $\mathrm{K}, \mathrm{Ti}$ and $\mathrm{Ca}$. Some samples have more $\mathrm{K}$ and $\mathrm{Ti}$ and others have more Ca.

Apart from the two major lithologies (i.e. limestone and alluvium), the geology of the Yucatán Peninsula is also characterized by presence of marl in limestone in both the Carillo Puerto Formation and Chichen Itza Formation (Servicio Geologico Mexicano, 2005a, 2005b). Additionally, shale and poorly consolidated sandstones are exposed in different parts of the peninsula (Servicio Geologico

Tree Diagram for 5 Variables

Complete Linkage

1-Pearson r

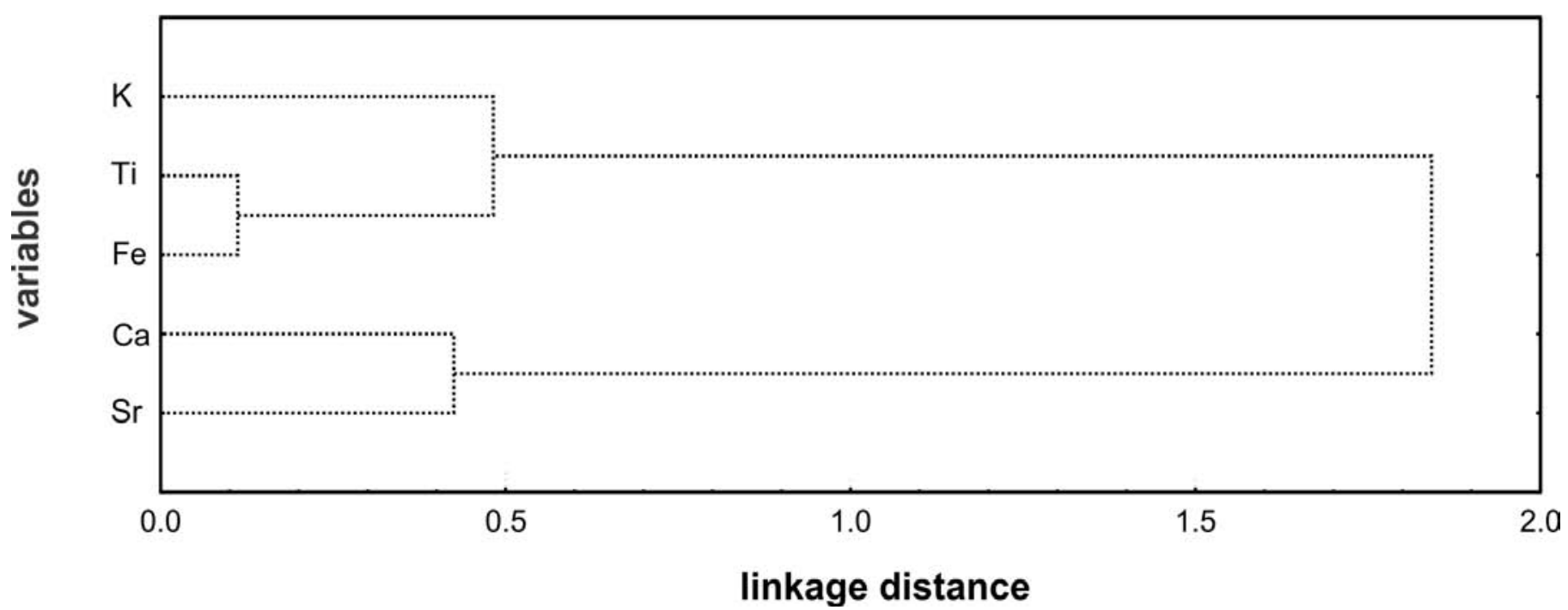

Figure 3. Tree-diagram of measured elements in surface sediments of the Yucatán Peninsula based on 1-Pearson-r and complete linkage methods. Association of $\mathrm{K}, \mathrm{Ti}$ and Fe represents the clastic minerals and association of $\mathrm{Ca}$ and $\mathrm{Sr}$ represents carbonates and evaporites. Figura 3. El diagrama de árbol de los elementos medidos en sedimentos superficiales de la Península de Yucatán, está basado en el método 1-Pearson-r y el de enlace completo. La asociación de K, Ti y Fe representa los minerales clásticos y la asociación de Ca y Sr representa los carbonatos y evaporitas. 
Mexicano, 2005a, 2005b). Relatively higher concentrations of $\mathrm{K}, \mathrm{Ti}$ and $\mathrm{Fe}$ in near-surface sediments of theYucatan Peninsula compared to the average limestone (Table 1; Mason and Moore, 1982) suggesting the influence of these clastic-rich sedimentary rocks. Erosion of different amounts of marl as well as sandstone and their different contributions in different parts of the peninsula led to variable amounts of $\mathrm{K}, \mathrm{Ti}$ and Fe being found in the surface sediments.

\section{Elemental concentration vs. precipitation}

Erosion of catchment rocks and subsequent transpor- tation of terrigenous clastic sediments by runoff occurs in a generally oxidizing environment with relatively uniform $\mathrm{pH}$ and temperature (Taylor and McLennan, 1985). Under such conditions, ionic potential controls transportation of different elements, either as particulate matter (oxides and association with hydroxyl groups) or in soluble state (Mason and Moore, 1982). Compared to soluble alkali (K) and alkaline earth ( $\mathrm{Ca}$ and $\mathrm{Sr}$ ) elements, the quadrivalent $\mathrm{Ti}$ and trivalent $\mathrm{Fe}$ remain immobile and insoluble. Similarly, the early soluble $\mathrm{K}$ subsequently adsorbs onto the finer clastic fractions and clay minerals due to its larger ionic radius. Thus, concentrations of $\mathrm{K}, \mathrm{Ti}$ and Fe reflect the abundance of the terrigenous clas-
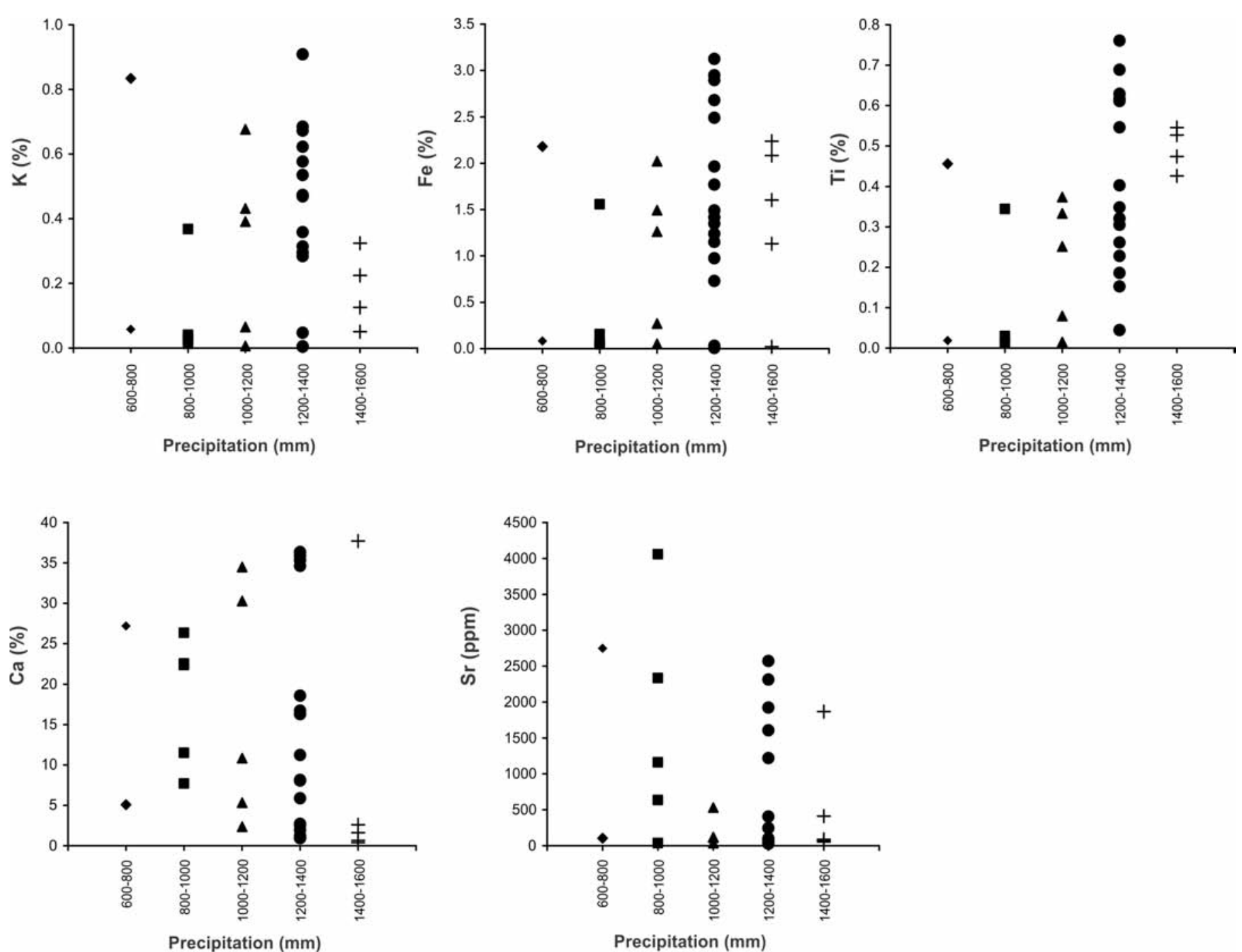

Figure 4. Binary plots showing concentrations of $\mathrm{K}, \mathrm{Ti}, \mathrm{Fe}, \mathrm{Ca}$ and $\mathrm{Sr}$ in near-surface sediments and mean annual precipitation of the sampling sites.

Figura 4. Los gráficos binarios muestran las concentraciones de K, Ti, Fe, Ca y Sr en sedimentos superficiales y la precipitación media anual de los sitios de muestreo. 
tic minerals transported by runoff. Higher precipitation and more runoff would deposit sediments with more $\mathrm{K}, \mathrm{Ti}$ and $\mathrm{Fe}$ and regimes of lower precipitation would deposit sediments with less $\mathrm{K}, \mathrm{Ti}$ and $\mathrm{Fe}$. Similarly, sediments deposited in regimes of lower precipitation would have more $\mathrm{Ca}$ and $\mathrm{Sr}$ as the soluble alkaline earth metals would deposit by precipitation of carbonates and evaporites.

We compared elemental concentrations of the surface sediments with mean annual precipitation of the sampling sites (Fig. 4) and expected to observe higher values of $\mathrm{K}, \mathrm{Ti}$ and $\mathrm{Fe}$ and lower $\mathrm{Ca}$ and $\mathrm{Sr}$ in sites with more annual precipitation compared to the sites that receive less annual precipitation. However, elemental concentrations are variable and do not show any clear trend with respect to precipitation. The concentration of $\mathrm{K}$ is $0.01 \%$ in one sample and $0.91 \%$ in another sample and both the samples were collected from locations that receive $1200-1400 \mathrm{~mm}$ of mean precipitation. Similarly, $\mathrm{Fe}$ is $0.05 \%$ in one sample and $2.02 \%$ in another sample collected from sites located in a region receiving $1000-1200 \mathrm{~mm}$ of rainfall. Samples with lower $\mathrm{K}$ and $\mathrm{Fe}$ have higher $\mathrm{Ca}$ and $\mathrm{Sr}$ and vice versa. As the elemental concentrations are expressed in relative abundance (i.e. weight percentage), variable concentration of elements represen-
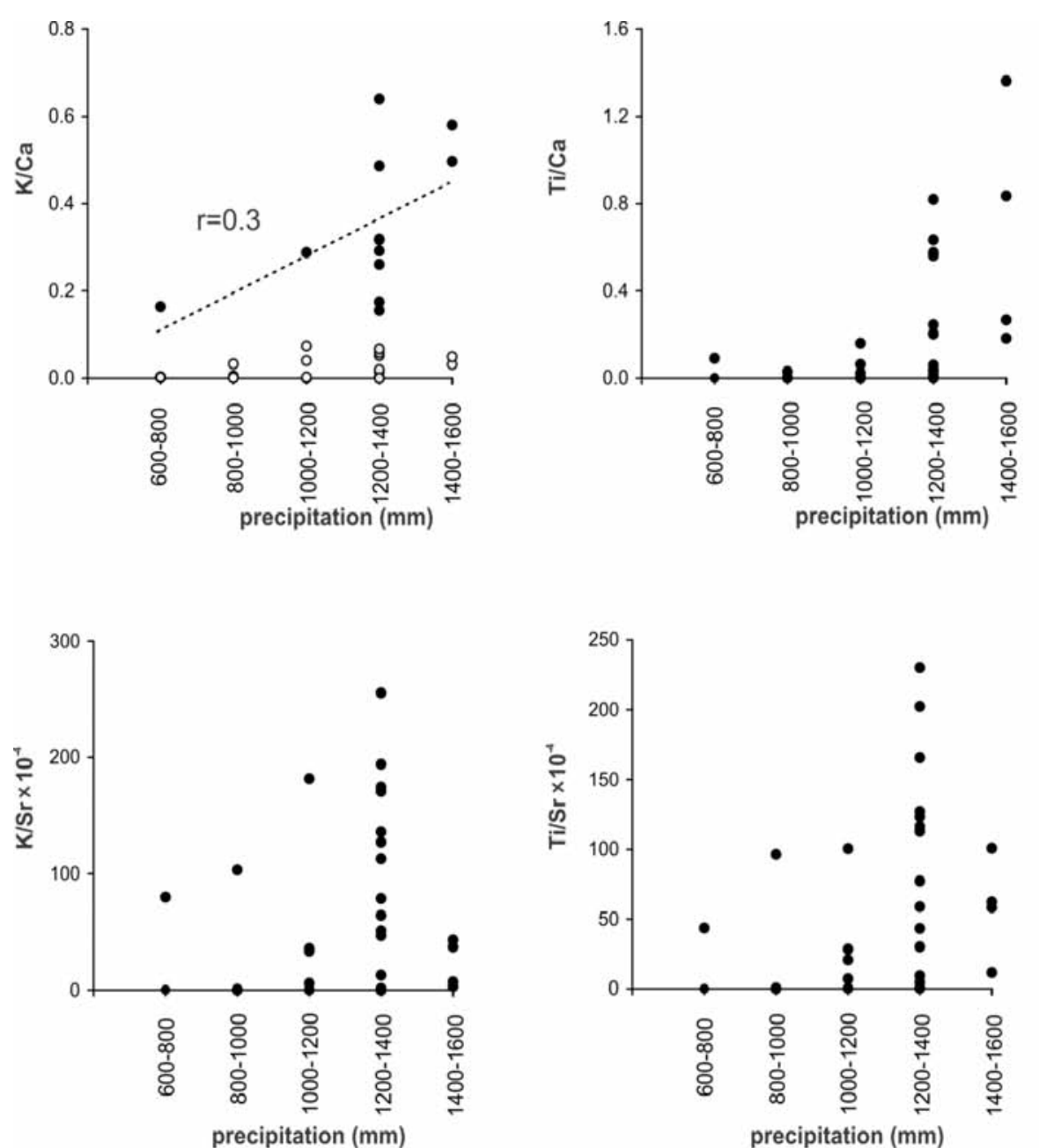
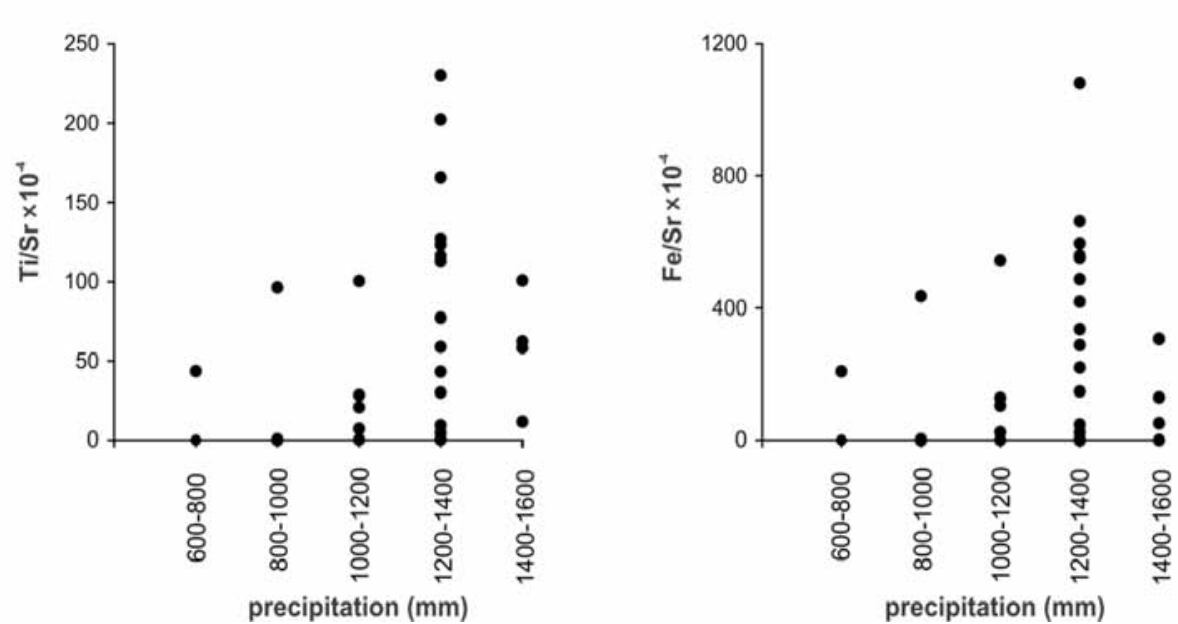

Figure 5. Binary plots showing elemental ratios of near-surface sediments and mean annual precipitation of the sampling sites. Samples with minimal clastics (open circles) exhibit lower and homogeneous element ratios irrespective of the amount of mean annual precipitation. Samples with more clastic minerals (filled circles) have variable values.

Figura 5. Los gráficos binarios muestran la relación elemental de los sedimentos superficiales y la precipitación media anual de los sitios de muestreo. Las muestras con un mínimo de clástos (círculos abiertos) exhiben proporciones de elementos más bajas y homogéneas, independientemente de la cantidad de la precipitación media anual. Las muestras con más minerales clásticos (círculos llenos) tienen valores altamente variables. 
ting the clastic mineral abundance from locations with comparable mean annual precipitation is a reflection of different degrees of dilution caused by the carbonates and evaporites. The cluster of elements associated with carbonates and evaporites exhibit negative correlations with the cluster of elements present in the terrigenous clastic minerals. Additionally, sediments sourced from catchments with minor amounts of marl and sandstone along with dominant limestone can have relatively higher concentrations of $\mathrm{K}, \mathrm{Fe}$ and $\mathrm{Ti}$ compared to samples sourced from catchments consisting of only limestone, although both the groups of sediments are collected from sites with comparable mean annual precipitation.

\section{Elemental ratio vs. precipitation}

We used ratios of elements associated with clastic minerals and elements present in carbonates and evaporites (i.e. $\mathrm{K} / \mathrm{Ca}, \mathrm{Ti} / \mathrm{Ca}$, $\mathrm{Fe} / \mathrm{Ca} \mathrm{K} / \mathrm{Sr}$, Ti/Sr and $\mathrm{Fe} / \mathrm{Sr}$ ) in order to minimize the dilution effect of carbonates and evaporites on the abundance of clastic minerals (e.g. Weltje and Tjallingii, 2008). Figure 5 shows the variation of elemental ratios in sediments with respect to mean annual precipitation. In general, the sediments with lower and homogenous values of elemental ratios are present in locations with less mean annual precipitation and they do not show any clear tendency as the mean annual precipitation increases. The lower values can be due to minimal abundances
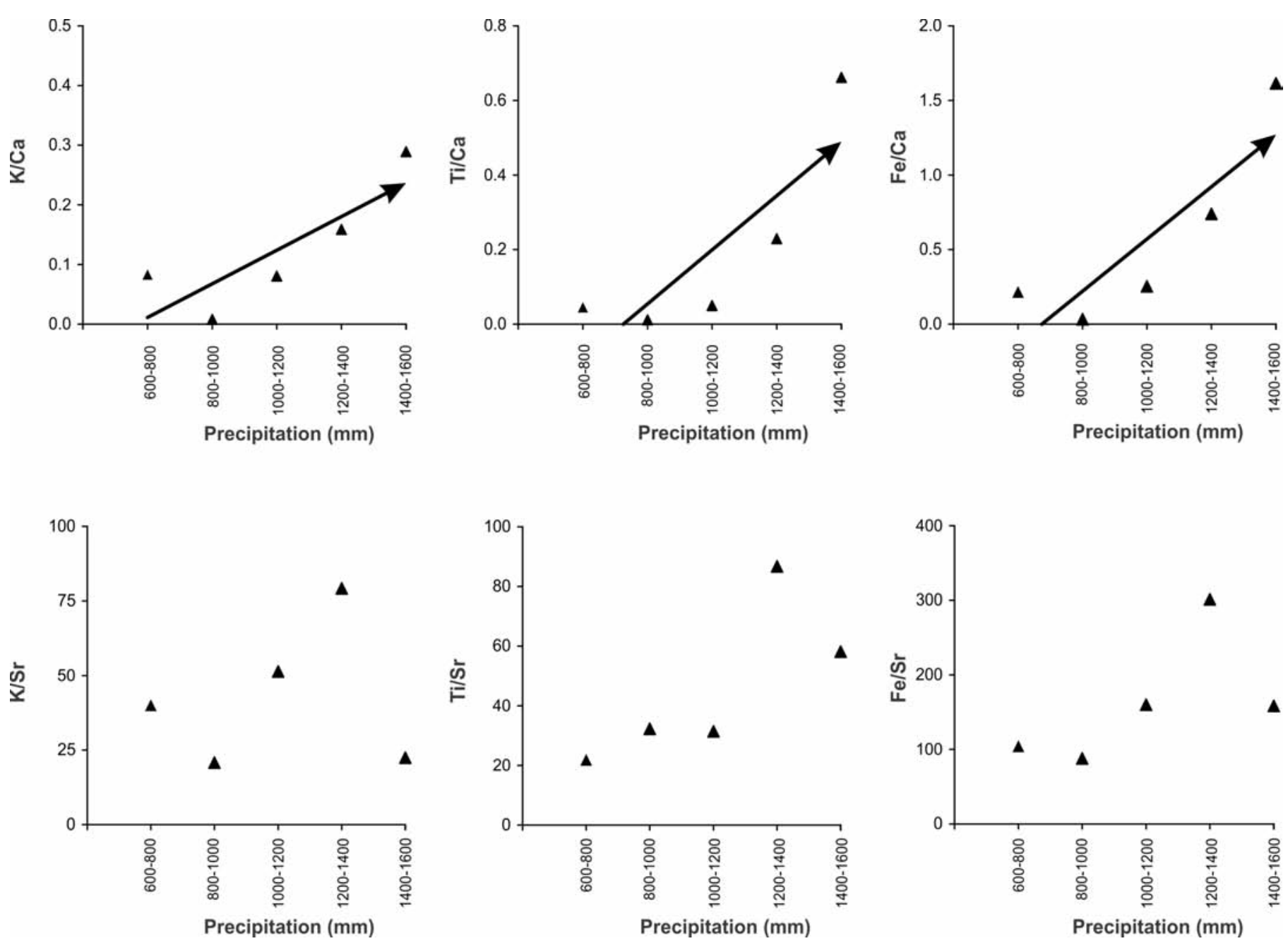

Figure 6. Tendencies of average values of $\mathrm{K} / \mathrm{Ca}, \mathrm{Ti} / \mathrm{Ca}, \mathrm{Fe} / \mathrm{Ca}, \mathrm{K} / \mathrm{Sr}, \mathrm{Fe} / \mathrm{Sr}$ and $\mathrm{Ti} / \mathrm{Sr}$ with respect to mean annual precipitation of the sampling sites.

Figura 6. Tendencias de los valores promedio de $\mathrm{K} / \mathrm{Ca}, \mathrm{Ti} / \mathrm{Ca}, \mathrm{Fe} / \mathrm{Ca}, \mathrm{K} / \mathrm{Sr}$. Fe/Sr y Ti/Sr con respecto a la precipitación media anual de los sitios de muestreo. 
of clastics as a result of less runoff into these sites as well as limestone-dominated catchments (Table 1). Sediments with minimal clastic minerals (i.e. less $\mathrm{K}, \mathrm{Ti}$ and $\mathrm{Fe}$ ) do not respond to the variable precipitation (open circles in Fig. 5). Among the sediments with a higher abundance of clastic minerals, the samples that were collected from locations with higher mean annual precipitation generally exhibited a higher element ratio compared to the sediments collected from sites with lower mean annual rainfall (filled circles in Fig. 5). However, the samples from the precipitation group of 1,200-1,400 $\mathrm{mm}$ have variable values of $\mathrm{K} / \mathrm{Ca}$ and samples from the groups of 1,200-1,400 $\mathrm{mm}$ and $1,400-1,600 \mathrm{~mm}$ have variable values of $\mathrm{Ti} / \mathrm{Ca}$ and $\mathrm{Fe} / \mathrm{Ca}$. Some of these values are similar or even lower than samples collected from other sites with relatively less mean annual precipitation. Biased sampling, as well as different composition of catchment geology in sites of comparable isohyets, may be the reasons. The number of samples from sites with mean annual precipitation of 1,200-1,400 $\mathrm{mm}$ is much higher $(n=18)$ compared to the samples collected from sites located within other precipitation groups $(n=2$ 5). Similarly, the varying amounts of clastic-rich marl and sandstone around the sampling sites with 1,200$1,400 \mathrm{~mm}$ and $1,400-1,600 \mathrm{~mm}$ of annual precipitation possibly contributed different abundances of $K$, $\mathrm{Fe}$ and Ti-bearing clastic sediments and hence the variable elemental ratios. We also observed that element/Ca ratios are better surrogates of precipitation compared to the element/Sr ratios as $\mathrm{K} / \mathrm{Sr}, \mathrm{Ti} / \mathrm{Sr}$ and $\mathrm{Fe} / \mathrm{Sr}$ are lower in sediments collected from locations of higher mean annual precipitation (i.e. 1,400-1,600 $\mathrm{mm}$ ) compared to sites that receive relatively less precipitation (i.e. 1,200-1,400 $\mathrm{mm}$ ).

In order to minimize the effects of biased sampling and variable catchment geology, the average values of $\mathrm{K} / \mathrm{Ca}, \mathrm{Ti} / \mathrm{Ca}, \mathrm{Fe} / \mathrm{Ca}, \mathrm{K} / \mathrm{Sr}, \mathrm{Ti} / \mathrm{Sr}$ and $\mathrm{Fe} / \mathrm{Sr}$ are compared with the mean annual precipitation (Fig. 6). Average values of the ratios of $\mathrm{K} / \mathrm{Ca}, \mathrm{Ti} / \mathrm{Ca}$ and $\mathrm{Fe} / \mathrm{Ca}$ show positive trends with respect to the precipitation. Sediments collected from sites with higher mean annual precipitation have higher ratios. However, this is a preliminary observation and further research is being carried out by increasing the number of samples as well as by improving the sample distribution in different precipitation regimes across the peninsula. Among the elemental ratios, $\mathrm{K} / \mathrm{Ca}$ ratio is a better proxy of precipitation as calcareous-sediments from the Yucatán Peninsula have lower concentration of Ti and $\mathrm{Fe}$ can be mobile in anoxic depositional environments. Many surface samples from the limestone-rich Yucatán Peninsula haveTi below the detection limit of portable Niton XRF spectrometer and even the con- ventional XRF could not measure Ti in six different samples. Similarly, the oxidation-reduction potential (Eh) can change in the post-deposition environment and lead to anoxic condition. Under such conditions, the insoluble Fe changes oxidation state and become mobile and soluble (Taylor and McLennan, 1985) and subsequently deposit as Fe-carbonate (e.g. siderite) or Fe-sulphide (e.g. pyrite) (Aller et al., 1986; Suits and Wilkin, 1998). Anoxic conditions near the sedimentwater interface of the Amazon River mouth led to presence of dissolved $\mathrm{Fe}$ and elevated $\mathrm{HCO}_{3}$ and caused the deposition of siderite (Aller et al., 1986). Suits and Wilkin (1998) reported pyrite formation in the water column of the Green Lake (near Fayetteville, New York) as a result of euxinic conditions. Similarly, Sheu and Presley (1986) observed iron sulfides in sediment from the anoxic Orca Basin of the Gulf of Mexico. Previous research on sub-surface sediments from different parts of the peninsula reports higher organic carbon contents (10-30\%, Leyden et al., 1996; 15-25\%, Gutiérrez-Ayala et al., 2012) and the possible existence of anoxic depositional environments. In such conditions, the Fe present in the sediments would not indicate the abundance of clastic minerals.

\section{Conclusions}

Most of the paleoecology and paleoclimate research in the Yucatán Peninsula of Mexico is based on fossil pollen in sediments of lakes, coastal swamps and marshes and there is hardly any proxy register that involves inorganic element concentrations in sedimentary archives. In this paper, we present concentrations of five different elements ( $\mathrm{K}, \mathrm{Ti}, \mathrm{Fe}, \mathrm{Ca}$ and $\mathrm{Sr}$ ) in 35 near-surface late Holocene sediment samples collected from different precipitation regimes across the peninsula. Elemental concentrations are compared with mean annual precipitation of the sampling sites in order to establish a proxy for precipitation after evaluating the effect of geology on sediment chemical composition. The main conclusions of this study are;

1. Sediments from sites with a similar catchment geology have dissimilar chemical compositions. Apart from the dominant limestone, the erosion of clastic-rich shale, marl and sandstone and their different contributions in different parts of the peninsula led to variable amounts of $\mathrm{K}, \mathrm{Ti}$ and $\mathrm{Fe}$.

2. Dilution effect of carbonates and evaporites on the clastic mineral abundance caused the lack of relationships of individual elemental concentrations and elemental ratios of sediments with minimal clastics with the mean annual precipitation. 
3. Element/Ca ratios are better surrogates for precipitation compared to the element/Sr ratios. In general, the average values of $\mathrm{K} / \mathrm{Ca}, \mathrm{Ti} / \mathrm{Ca}$ and $\mathrm{Fe} / \mathrm{Ca}$ in sediments with higher clastic abundance increase with respect to increasing mean annual precipitation. However, the sampling protocol and presence of most of the sampled water bodies being in a single precipitation cluster (i.e. 1,200-1,400 mm/year) did not allow a complete evaluation of the potential correlation between precipitation and elemental ratios in near-surface sediments of the Yucatán Peninsula. In a preliminary observation, the $\mathrm{K} / \mathrm{Ca}$ ratio could be used as a proxy to infer paleo-precipitation as sedimentary records in the karstic terrain have low $\mathrm{Ti}$ and $\mathrm{Fe}$ is mobile in anoxic environments.

\section{Acknowledgements}

Data in this manuscript were generated during the sabbatical of the first author with a PASPA scholarship from DGAPA-UNAM. Samples were analyzed in the Instituto de Geología (UNAM). CONACYT project N181997 “Reconstrucción de Paleoambientes y Modelación Climática de la región oeste de la Península de Yucatán" provided financial support for sampling and analysis. We are grateful for the suggestions and comments from both the anonymous reviewers and the editor ( $\mathrm{Dr}$. Josué M. PolancoMartínez).

\section{References}

Aller, R.C., Mackin, J.E. and Cox Jr, R.T. 1986. Diagenesis of Fe and $S$ in Amazon inner shelf muds: apparent dominance of Fe reduction and implication for the génesis of ironstones. Continental Shelf Research, 6 (1-2), 263-289.

Aragón-Moreno, A.A., Islebe, G.A. and Torrescano-Valle, N. 2012. A 3800-yr, high resolution record of vegetation and climate change on the north coast of the Yucatan Peninsula. Review of Palaeobotany and Palynology, 178, 35-42.

Carrillo-Bastos, A., Islebe, G.A., Torrescano-Valle, N. and González, N.E. 2010. Holocene vegetation and climate history of central Quintana Roo, Yucatan Peninsula, Mexico. Review of Palaeobotany and Palynology, 160, 189-196.

Cohen, A.S. 2003. Palaeolimnology: The History and Evolution of Lake Systems. Oxford University Press, New York, 528 pp.

Curtis, J.H., Hodell, D.A. and Brenner, M. 1996. Climate variability on the Yucatan Peninsula (Mexico) during the past 3500 years, and implications for Maya cultural evolution. Quaternary Research, 46, 37-47.

Gutiérrez-Ayala, L.V., Torrescano-Valle, N. and Islebe, G.A. 2012. Reconstrucción paleoambiental del Holoceno
Tardío de la reserva Los Petenes, Península de Yucatán, México. Revista Mexicana de Ciencias Geológicas, 29, 749-763.

Haug, G.H., Guenther, D., Peterson, L.C., Sigman, D.M., Hughen, K.A. and Aeschlimann, B. 2003. Climate and the collapse of Maya civilization. Science, 299, 1731-1735.

Haug, G.H., Hughen, K.A., Sigman, D.M., Peterson, L.C. and Roehl, U. 2001. Southward migration of the Intertropical Convergence Zone through the Holocene. Science, 293, 1304-1308.

Hodell, D.A., Brenner, M. and Curtis, J.H. 2005. Terminal Classic drought in the northern Maya lowlands inferred from multiple sediment cores in Lake Chichancanab (Mexico). Quaternary Science Reviews, 24, 1413-1427.

INEGI 2006. Conjunto de datos vectoriales de precipitación media anual, Escala. 1:1000, 000.

Islebe, G. and Sánchez, O. 2002. History of Late Holocene vegetation at Quintana Roo, Caribbean coast of Mexico. Plant Ecology, 160, 187-192.

Leyden, B.W., Brenner, M., Whitmore, T., Curtis, J.H., Piperno, D.R. and Dahlin, B.H. 1996. A record of longterm and short-term climatic variation from northwest Yucatán: Cenote San José Chulchacá. In: Fedick, S.L. (ed.), The managed mosaic: ancient Maya agriculture and resource use. University of Utah Press, Salt Lake City, 30-50.

Lozano-García S., Ortega B., Roy P.D., Beramendi-Orosco L. and Caballero, M. 2015. Climatic variability in the northern sector of the American tropics since the latest MIS 3. Quaternary Research, 84(2), 262-271.

Lozano-Santacruz, R., Verma, S.P., Girón, P., Velasco, F., Morán-Zenteno, D., Viera, F. and Chávez, G. 1995. Calibración preeliminar de Fluorescencia de Rayos-X para análisis cuantitativo de elementos mayores en rocas ígneas. Actas INAGEQ, 1, 203-208.

Masson-Delmotte, V., Schulz, M., Abe-Ouchi, A., Beer, J., Ganopolski, A., Gonzalez Rouco, J.F., Jansen, E., Lambeck, K., Luterbacher, J., Naish, T., Osborn, T., OttoBliesner, B., Quinn, T., Ramesh, R., Rojas, M., Shao X. and Timmermann, A. 2013. Information from paleoclimate archives. In: Stocker, T.F., Qin, D., Plattner, G.-K., Tignor, M., Allen, S.K., Boschung, J., Nauels, A., Xia, Y., Bex V. and Midgley, P.M. (eds.), Climate Change 2013: The Physical Science Basis. Contribution of Working Group I to the Fifth Assessment Report of the Intergovernmental Panel on Climate Change. Cambridge University Press, Cambridge, 383-464.

Magaña, V., Amador, J.A. and Medina, S. 1999. The midsummer drought over Mexico and Central America. Journal of Climate, 12, 1577-1588.

Mason, B. and Moore, C.B. 1982. Principles of Geochemistry. John Wiley \& Sons, New York, 352 pp.

Mendoza, B., Velasco, V. and Jauregui E. 2006. A study of historical droughts in southeastern Mexico. Journal of Climate, 19, 2916-2934.

Metcalfe S., Jones M.D., Davies S.J., Noren A. and Mackenzie A. 2010. Climate variability over the last two millennia in the North American Monsoon region, recorded in laminated lake sediments from Laguna Juanacatlán México. The Holocene, 20, 1195-1206. 
Nesbitt, H.W. and Young, G.M. 1982. Early Proterozoic climates and plate motions inferred from major element chemistry of lutites. Nature, 299, 715-717.

Peterson, L.C. and Haug, G.H. 2006. Variability in the mean latitude of the Atlantic Intertropical Convergence Zone as recorded by riverine input of sediments to the Cariaco Basin (Venezuela). Palaeogeography, Palaeoclimatology, Palaeoecology, 234, 97-113.

Roy, P.D., Caballero, M., Lozano, R., Ortega, B., Lozano, S., Pi, T., Israde, I. and Morton, O. 2010. Geochemical record of Late Quaternary paleoclimate from lacustrine sediments of paleo-lake San Felipe, western Sonora Desert, Mexico. Journal of South American Earth Sciences, 29, 586-596.

Roy, P.D., Chávez-Lara, C.M., Beramendi-Orosco, L.E., Sánchez-Zavala, J.L., Muthu-Sankar, G., LozanoSantacruz, R., Quiroz-Jimenez, J.D. and López-Balbiaux, N. 2015. Pleohydrology of the Santiaguillo Basin (Mexico) since late last glacial and climate variation in southern part of western subtropical North America. Quaternary Research, 84, 335-347.

Roy, P.D., Quiroz-Jiménez, J.D., Pérez-Cruz, L.L., LozanoGarcía, S., Metcalfe, S.E., Lozano-Santacruz, R., LópezBalbiaux, N., Sánchez-Zavala, J.L. and Romero, F.M. 2013. Late Quaternary paleohydrológical conditions in the dryland of northern Mexico: a summer precipitation proxy record of the last $80 \mathrm{cal}$ ka BP. Quaternary Science Reviews, 78, 342-354.

Roy, P.D., Rivero-Navarrete, A., Sánchez-Zavala, J.L., Beramendi-Orosco, L.E., Muthu-Sankar, G. and LozanoSantacruz, R. 2016. Atlantic Ocean modulated hydroclimate of the subtropical northeastern Mexico since the Last Glacial Maximum and comparison with the sou-thern US. Earth and Planetary Science Letters, 434, 141-150.

Servicio Geologico Mexicano 2005a. Carta Geológico Tizimín, F16-7, Escala 1:250,000, Estado de Yucatán. Servicio Geologico Mexicano 2005b. Carta Geológico
Minera y Geoquimica Mérida, F16-10, Escala 1:250,000, Estado de Yucatán, Campeche y Quintana Roo.

Sheu, D.D. and Presley, B.J. 1986. Variations of calcium carbonate, organic carbón and iron sulfides in anoxic sediment from the Orca Basin, Gulf of Mexico. Marine Geology, 70 (1-2), 103-118.

Sosa-Nájera, S., Lozano-García, S. and Roy, P.D. and Caballero, M. 2010. Registro de sequías históricas en el occidente de México con base en el análisis elemental de sedimentos lacustres: El caso del lago de Santa María del Oro. Boletín de la Sociedad Geológica Mexicana, 62(3), 437-451.

Suits, N.S. and Wilkin, R.T. 1998. Pyrite formation in the water column and sediment of a merimictic lake. Geology, 26 (12), 1099-1102.

Taylor, S.R. and McLennan S.M. 1985. The continental crust: its composition and evolution. Blackwell Scientific Publications, Oxford, 312 pp.

Torrescano, N. and Islebe, G.A. 2006. Tropical forest and mangrove history from southeastern Mexico: a $5000 \mathrm{yr}$ pollen record and implications for sea level rise. Vegetation History and Archaeobotany, 15, 191-195.

Torrescano-Valle, N. and Islebe, G.A. 2012. Mangroves of Southeastern Mexico: Palaeoecology and Conservation. The Open Geography Journal, 5, 6-15.

Torrescano-Valle, N. and Islebe, G.A. 2015. Holocene paleoecology, climate history and human influence in the southwestern Yucatan Peninsula. Review of Palaeobotany and Palynology, 217, 1-8.

Verma, S.P., Lozano-Santacruz, R., Girón-García, P. and Velasco, F. 1996. Calibración preliminar de Fluorescencia de Rayos-X para análisis cuantitativo de elementos traza en rocas ígneas. Actas INAGEQ, 2, 237-242.

Weltje, G.J. and Tjallingii, R. 2008. Calibration of XRF core scanners for quantitative geochemical logging of sediment cores: Theory and application. Earth and Planetary Science Letters, 274, 423-438.

Recibido: junio 2017

Revisado: diciembre 2017

Aceptado: febrero 2018

Publicado: diciembre 2018 